\title{
PENGAMBILAN KEPUTUSAN BAGI PERAWAT SECARA KRITIS
}

Mahdalena Br Surbakti

\section{Email : magdalenakurus15@gmail.com}

\begin{abstract}
The purpose of writing this study is to describe how the processes and models are used to increase the knowledge and skills of nurses in making decisions by using the concept of critical thinking so that all parties concerned can be accepted and do not harm any party. Nurses must be able to identify patient problems and choose appropriate intervention solutions, because nurses will face various clinical situations related to patients where this cannot be separated from the ability to think critically because by thinking critically nurses can make decisions systematically and accurately at every stage. nursing care performed. Nurses who think critically have a 2,403 times chance of being able to perform nursing care well when compared to nurses who are less critical. It is hoped that the nurse will hone and train critical thinking skills through the implementation of the nursing round.
\end{abstract}

Keywords: Critical Thinking, Decision Making, Nurse Role.

\begin{abstract}
ABSTRAK
Penulisan kajian ini bertujuan untuk memaparkan bagaimana proses serta model-model yang digunakan untuk meningkatkan pengetahuan dan ketrampilan perawat dalam mengambil keputusan dengan menunggunakan konsep berfikir kritis sehingga bisa diterima semua pihak yang bersangkutan tidak merugikan pihak manapun. Perawat harus mampu mengidentifikasi masalah pasien dan memilih solusi intervensi yang tepat, karena perawat akan menghadapi bermacam-macam situasi klinis yang berhubungan dengan pasien dimana hal ini tak lepas dari
\end{abstract}


kemampuan berpikir kritis karena dengan berpikir kritis perawat dapat mengambil keputusan secara sistematis dan tepat dalam setiap tahapan asuhan keperawatan yang dilakukan. Perawat yang berpikir kritis berpeluang 2,403 kali mampu melakukan asuhan keperawatan dengan baik jika dibandingkan dengan perawat yang kurang berpikir kritis. Diharapkan perawat mengasah dan melatih kemampuan berpikir kritis melalui pelaksanaan ronde keperawatan.

\section{Kata Kunci : Berpikir Kritis, Pengambilan Keputusan, Peran Perawat.}

\section{Latar Belakang}

Keselamatan pasien (patient safety) adalah suatu sistem dimana rumah sakit membuat asuhan pasien lebih aman, mencegah terjadinya cidera yang disebabkan oleh kesalahan akibat melaksanakan suatu tindakan atau tidak mengambil tindakan yang seharusnya diambil. Sistem tersebut meliputi pengenalan resiko, identifikasi dan pengelolaan hal yang berhubungan dengan resiko pasien, pelaporan dan analisis insiden, kemampuan belajar dari insiden, tindak lanjut dan implementasi solusi untuk meminimalkan resiko (Depkes 2008).

Kemampuan berpikir kritis sangat diperlukan dalam pelaksanaan asuhan keperawatan di rumah sakit. Peningkatan kemampuan berpikir kritis akan meningkatkan kualitas asuhan keperawatan dalam mengambil keputusan dan tindakan untuk menangani pasien di rumah sakit. Sepanjang komponen dari proses keperawatan, perawat menggunakan sikap dan kemampuan berpikir kritis untuk menentukan relevansi, makna dan iterrelasi data pasien serta untuk memilih dan menetapkan asuhan keperawatan yang sesuai. Berpikir kritis penting dilakukan sebelum mengambil keputusan dalam asuhan keperawatan karena merupakan salah satu metode ilmiah dalam menyelesaikan masalah klien. Kemampuan perawat mengidentifikasi masalah klien dan memilih solusi intervensi yang tepat tidak lepas dari kemampuan perawat berpikir kritis untuk menggali berbagai alasan berdasarkan evidence base dari setiap problem dan solusi yang teridentifikasi. Berpikir kritis menjadi bagian yang tidak terpisahkan dari asuhan keperawatan yang dilakukan oleh perawat. Berpikir kritis penting dilakukan sebelum mengambil keputusan dalam asuhan keperawatan karena berpikir kritis dalam keperawatan merupakan keterampilan berpikir perawat untuk menguji berbagai alasan secara rasional sebelum mengambil keputusan dalam asuhan keperawatan. Hal tersebut dikuatkan oleh penelitian yang dilakukan oleh Aprisunadi (2011) yang mengatakan bahwa terdapat hubungan yang bermakna antara berpikir kritis perawat dengan kualitas diagnosis keperawatan di unit orthopedic yang ditunjukkan dengan hasil penelitian yang dilakukan dari 45 responden perawat di ruang orthopedic didapatkan $25(78,1 \%)$ responden yang memiliki kecendrungan berpikir kritis mempunyai peluang 5,714 kali untuk membuat diagnosis yang berkualitas dibandingkan dengan responden yang tidak cenderung berpikir kritis.

Sikap etis profesional yang kokoh dari setiap perawat akan tercermin dalam setiap langkahnya, termasuk penampilan diri serta keputusan yang diambil dalam merespon situasi yang muncul. Oleh karena itu pemahaman yang mendalam tentang etik dan moral serta penerapannya menjadi bagian yang sangat penting dan mendasar dalam memberikan asuhan keperawatan dimana nilai-nilai pasen selalu menjadi pertimbangan dan dihormati. 
Perawat profesional harus menghadapi tanggung jawab etik dan konflik yang mungkin meraka alami sebagai akibat dari hubungan mereka dalam praktik profesional. Kemajuan dalam bidang kedokteran, hak klien, perubahan sosial dan hukum telah berperan dalam peningkatan perhatian terhadap etik. Standar perilaku perawat ditetapkan dalam kode etik yang disusun oleh asosiasi keperawatan internasional, nasional, dan negera bagian atau provinsi. Perawat harus mampu menerapkan prinsip etik dalam pengambilan keputusan dan mencakup nilai dan keyakinan dari klien, profesi, perawat, dan semua pihak yang terlibat. Perawat memiliki tanggung jawab untuk melindungi hak klien dengan bertindak sebagai advokat klien.

Standar praktik keperawatan profesional di Indonesia telah dijabarkan oleh Persatuan Perawat Nasional Indonesia (PPNI) pada tahun 2000. Standar tersebut mengacu pad proses keperawatan yang terdiri atas lima tahap yaitu pengkajian, doagnosis, perencanaan, implementasi dan evaluasi. Proses keperawatan adalah satu pendekatan untuk pemecahan masalah yang memampukan perawat untuk mengatur dan memberikan asuhan keperawatan.

\section{Metode}

Metode yang digunakan adalah metode kualitatif dengan cara mengumpulkan sebanyak-banyaknya data untuk dianalisis. Yaitu dengan literature review dengan menganalisis yang berfokus pada penerapan kebijakan keselamatan pasien di rumah sakit. Adapun tinjaun literature review yang digunakan seperti text book, journal, dan referensi lainnya.

\section{Hasil}

Berdasarkan hasil pengkajian kualitatif tersebut dapat diketahui metode yang digunakan untuk mengetahui apa saja peran perawat yang akan dilakukan untuk keselamatan pasien, yaitu meliputi Metode Pengumpulan Data dimana dalam penelitian kualitatif beberapa metode pengumpulan data dalam penelitian kualitatif ini dapat meningkatkan kemampuan perawat dalam berfikir kritis. Sehingga dengan adanya pengumpulan data ini akan membuat mahasiswa lebih banyak membaca baik itu buku maupun jurnal dan ini akan lebih mudah meningkatkan kemampuan berpikir kritis tersebut. Indikator mutu rumah sakit meliputi indikator klinik, indikator yang berorientasi pada waktu dan indicator ratio yang berdasarkan pada efektifitas (effectivenes), efisiensi (efficiency), keselamatan (safety) dan kelayakan (appropriateness).

\section{Pembahasan}

Saat ini dunia keperawatan di Indonesia sedang mengalami perkembangan yang sangat pesat.

Bidang kesehatan telah menjadi industri dengan pertumbuhan yang luar biasa dan dengan sendirinya kebutuhan akan tenaga perawat yang profesional dan kompeten di bidangnya meningkat pula.

Di satu sisi, perkembangan ini merupakan suatu kesempatan bagi tenaga keperawatan di Indonesia untuk meningkatkan eksistensinya dalam dunia kesehatan, sehingga dapat bersanding secara sejajar dengan profesi lainnya. Namun, di sisi lain perkembangan ini juga merupakan tantangan bagi insan keperawatan Indonesia untuk membuktikan kemampuannya.

Bila tenaga keperawatan Indonesia tidak segeraberbenah diri baik dari segi kompetensi maupun administrasi, maka kesempatan tersebut tidak dapat dimanfaatkan dengan seefektif

mungkin hingga bidan keperawatan Indonesia akan ketinggalan dibandingkan tren dunia internasional. 
Kemampuan dan ketrampilan dalam membuat keputusan, terutama dalam masalah kedaruratan merupakan hal yang sangat penting. Dalam konseling, pengambilan keputusan mutlak ada di tangan klien, sedangkan dokter dan perawat membantu klien supaya keputusan yang diambil merupakan suatu keputusan yang tepat.

Dalam penerapan pembelajaran pemikiran kritis di keperawatan, dapat digunakan tiga model, yaitu: feeling, vision model, dan examine model yaitu sebagai berikut:

1. Feling model, Model ini menerapkan pada rasa, kesan, dan data atau fakta yang ditemukan. Pemikir kritis mencoba mengedepankan perasaan dalam melakukan pengamatan, kepekaan dalam melakukan aktifitas keperawatan dan perhatian. Misalnya terhadap aktifitas dalam pemeriksaan tanda vital, perawat merasakan gejala, petunjuk dan perhatian kepada pernyataan serta pikiran klien.

2. Vision model, Model ini dingunakan untuk membangkitkan pola pikir, mengorganisasi dan menerjemahkan perasaan untuk merumuskan hipotesis, analisis, dugaan dan ide tentang permasalahan perawatan kesehatan klien, beberapa kritis ini digunakan untuk mencari prinsipprinsip pengertian dan peran sebagai pedoman yang tepat untuk merespon ekspresi.

3. Exsamine model, Model ini dungunakan untuk merefleksi ide, pengertian dan visi. Perawat menguji ide dengan bantuan kriteria yang relevan. Model ini digunakan untuk mencari peran yang tepat untuk analisis, mencari, meguji, melihat konfirmasi, kolaborasi, menjelaskan dan menentukan sesuatu yang berkaitan dengan ide.

Selain itu, perawat juga berperan untuk memberikan informasi kepada pasien dan keluarga tentang kemungkinan terjadinya resiko,melaporkan terjadinya KTD, meningkatkan komunikasi dengan pasien dan tenaga kesehatan professional lainnya, berperan aktif dalam melakukan pengkajian terhadap keamanan dan kualitas pelayanan dan membantu pengukuran terhadap peningkatan patient safety (Choo,2010). Sebagai contoh yaitu peran perawat dalam penggunaan peralatan dan teknologi dalam meningkatkan patient safety.

Proses pengambilan keputusan dengan konsep berfikir kritis terbagi menjadi dua juga. Pengambilan keputusan dalam keperawatan merupakan adalah hal yang sangat penting karena akan memengaruhi asuhan keperawatan yang karena diberikan. Pengambilan keputusan ini sendiri mencakup semua penilian dari segala aspek dan kegiatan yang diperlukan guna untuk mencari pilihan keputusan yang terbaik. Sesuai model pengambilan keputusan terdapat dua proses pengambilan keputusan yaitu proses rutin dalam pengambilan keputusan terprogram dan proses kreatif dalam pengambilan keputusan tak terprogram.

\section{UPAYA-UPAYA PENGAMBILAN} KEPUTUSAN

(1) Membantu klien meninjau kemungkinan pilihannya;

(2) Membantu klien dalam mempertimbangkan keputusan pilihan;

(3) Membantu klien mengevaluasi pilihan;

(4) Membantu klien menyusun rencana kerja. 


\section{ELEMEN-ELEMEN DASAR PENGAMBILAN KEPUTUSAN \\ * Menetapkan tujuan \\ * Mengidentifikasi permasalahan \\ * Mengembangkan sejumlah alternatif \\ * Penilaian dan pemilihan alternatif \\ * Melaksanakan keputusan \\ * Evaluasi dan pengendalian}

Pelaksanaan elemen dalam mencapai kolaborasi efektif dilakukan dengan cara: Pelaksanaan Kerjasama (Cooperation) dimana pelaksanaan kerjasama antara perawat dan dokter telah dilakukan dengan saling memberi pertimbangan, mengoreksi, serta melengkapi satu sama lain. Pada kenyataannya, member pertimbangan maupun memberi koreksi saja tidak cukup untuk mewujudkan pelaksanaan kerjasama yang baik. Satu hal terpenting yaitu kesediaan masing masing anggota tim untuk mengubah pandangan dan perspektif pribadi (Way, 2000) dengan melaksanakan pertimbangan maupun koreksi tidak dijelaskan oleh partisipan. Pelaksanaan asertivitas ditunjukkan dengan saling care, menolak ketika tidak sesuai dengan yang diharapkan, menanggapi perbedaan pendapat dalam segi positif, terbuka, menerima, mendengarkan, dan berkomunikasi dengan baik. Hal tersebut sesuai dengan makna asertivitas sebagai kemampuan untuk mengemukakan pikiran, perasaan, pendapat secara langsung dan jujur dengan cara penyampaian yang tepat sehingga tidak menyakiti atau merugikan diri sendiri maupun orang lain (Rumanti, 2009).

\section{Penutup}

Ada pengaruh berpikir kritis terhadap kemampuan perawat dalam melakukan asuhan keperawatan dan perawat yang berpikir kritis berpeluang 2,403 kali mampu melakukab asuhan keperawatan dengan baik jika dibandingkan dengan perawat yang kurang berpikir kritis. Ada pengaruh lama kerja terhadap kemampuan perawat pelaksana dalam melakukan asuhan keperawatan dan lama kerja merupakan faktor dominan dari counfounding terhadap kemampuan perawat dalam melakukan asuhan keperawatan dan didapatkan bahwa perawat yang memiliki lama kerja lebih dari 10 tahun berpeluang 2,144 kali mampu melakukan asuhan keperawatan dengan baik jika dibandingkan dengan perawat yang lama kerjanya kurang dari10 tahun. Tidak ada hubungan antara jenis kelamin dengan kemampuan berpikir kritis, tidak ada hubungan umur dengan kemampuan berpikir kritis perawat, tidak ada hubungan antara tingkat pendidikan dengan kemampuan berpikir kritis, tidak ada hubungan antara kecerdasan emosional dengan kemampuan berpikir kritis perawat dan tidak ada hubungan antara motivasi dengan kemampuan berpikir kritis seorang perawat.

Daftar Pustaka

1. Aprisudi. 2011. Hubungan berpikir kritis Perawat dengan Kualitas Asuhan Keperawatan Di Unit Perawatan Orthopedi di Rumah Sakit Umum Pusat Fatmawati Jakarta. Tesis FIK UI. Tidak Dipublikasikan

2.Arif, Yulastri,. (2013). Efektivitas Model Strategi Manajemen Konflik Perawat Pelaksana terhadap Produktivitas Kerja Perawat di Rumah Sakit Pendidikan. Manuskrip program doktoral. Depok : FIK UI

3. Deniati, dkk. (2018). Pengaruh Berfikir Kritis Terhadap Kemampuan Perawat Pelaksana Dalam Melakukan Asuhan Keperawatan di Rumah Sakit Hermina Bekasi Tahun 2016. Jurnal Kesehatan Holistik, 12(1), 21-24.

4.Magdalena Hilyah .2017.Analisis Faktor Faktor Pendukung Pengambilan Keputusan 
Memilih Rumah Sakit Rujukan Di Bangka Belitung Dengan Analitycal Hierarchy Process. Sistem Informasi, STMIK Atma Luhur. Volume 2 No. 2.

5.Rachmawati Kiki,dkk. PENERAPAN CART PADA SISTEM PENDUKUNG PENGAMBILAN KEPUTUSAN (SPPK) STUDI KASUS MENENTUKAN OBAT SESUAI KONDISI PASIEN. Teknik Informatika, Fakultas Teknik Informatika, Universitas Telkom.

6.Rahaminta, Brita Madya Sulisno.2012. Pengalaman Perawat Berkolaborasi dengan Dokter di Ruang ICU. JURNAL NURSING STUDIES, Volume 1, Nomor 1 Tahun 2012, Halaman $74 \pm 80$.

7.Rivai, F.,dkk. (2016). Faktor Yang Berhubungan Dengan Implementasi

Keselamatan Pasien Di Rsud Ajjappannge Soppeng Tahun 2015. Jurnal Kebijakan Kesehatan Indonesia. Vol. 5(4). Hal 155156.

8.Sari Rohni Taufika.2019.STUDI FENOMENOLOGI: PERSPEKTIF PERAWAT MENGENAI PERSONAL HYGIENE KLIEN DI INSTALASI RAWAT INAP

(phenomenology study: nursing perspective on personal hygiene clients in installation of hospital). Fakultas Keperawatan dan Ilmu Kesehatan. Vol. 3 No. 2.

9. Simamora, R. H.(2005).Hubungan Presepsi Perawat Pelaksanaan Terhadap Penerapan Fungsi Pengorganisasian Yang Dilakukan Oleh Kepala Ruangan Dengan Kinerjanya Diruang Rawat Inap RSUD Kota Jakarta Utara ( Doctoraldissertation, Tesis FIK UI, Tidak dipublikasikan).

10. Simamora, R. H. (2018). Buku Ajar Keselamatan Pasien Melalui Timbang
Terima Pasien Berbasis Komunikasi Efektif: SBAR.

11.Simamora, R. H. (2019). Menjadiperawat yang: CIH'HUY. Surakarta: Kekata Publisher.

12. Yulia, S., Yani, A. (2012). Peningkatan Pemahaman Perawat Pelaksana

Dalam Penerapan Keselamatan Pasien Melalui Pelatihan Keselamatn Pasien. Jurnal

keperawatan indonesia. Vol. 15(3). Hal 190.5 